\title{
Two New Antifungal Alkaloids Produced by Streptoverticillium morookaense
}

\author{
Na Feng, Wanhui Ye, Ping Wu, Yicun Huang, Haihui Xie, Xiaoyi Wei
}

Received: September 23, 2006 / Accepted: February 10, 2007

(C) Japan Antibiotics Research Association

\begin{abstract}
A new carbazole alkaloid, streptoverticillin, and a new 2-azetidinone, streptoverticillinone, along with three known cyclodipeptides were isolated from the mycelial solid culture of Streptoverticillium morookaense. Their structures were elucidated by analysis of 1D and 2D NMR, mass spectra and optical rotation data. Two new compounds exhibited antifungal activity against Peronophythora litchii.
\end{abstract}

Keywords Streptoverticillium, alkaloids, streptoverticillin, streptoverticillinone, antifungal

\section{Introduction}

Litchi (Litchi chinensis Sonn.) is a tropical and subtropical fruit with luscious flavor and attractive appearance. One of the major limitations to its commercial value is the rapid rot after harvest, which is caused by phytopathogenic fungi. Although the currently used synthetic fungicides, such as carbendazim, prochloraz, and benomyl are effective in controlling postharvest rot [1], there is need for novel agents. The available fungicides aroused increasing public concern regarding contamination with residues and proliferation of antifungal resistance in the pathogen populations. Microorganisms have proved to be a rich source of bioactive secondary metabolites, and numerous compounds with potent biological activities and unique chemical structures have been isolated [2]. In screening for new antibacterial and antifungal metabolites produced by

X. Wei (Corresponding author), N. Feng, W. Ye, P. Wu, Y. Huang, H. Xie: South China Botanical Garden, Chinese Academy of Sciences, Xingke Road 723, Tianhe District, Guangzhou 510650, China, E-mail: wxy@scbg.ac.cn microorganisms isolated in South China [3, 4], an EtOH extract from a mycelial solid culture of Streptoverticillium morookaense was found to show antifungal activity against Peronophythora litchii, one of the main pathogens causing litchi fruit rot. We investigated the secondary metabolites of this actinomycete and isolated and characterized a new carbazole alkaloid, trivially named streptoverticillin (1), and a new 2-azetidinone, streptoverticillinone (2), with antifungal activity against $P$. litchii, along with three known cyclodipeptides. We herein report the isolation, structure elucidation, and antifungal activity of these two new compounds.

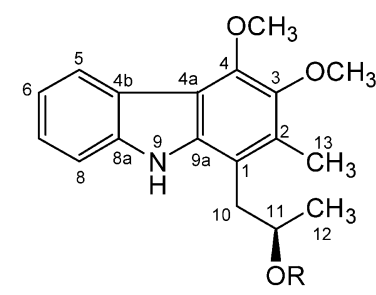

Streptoverticillin (1) $\mathrm{R}=\mathrm{H}$

1a $\mathrm{R}=(R)-\mathrm{MTPA}$

1b $\mathrm{R}=(S)-\mathrm{MTPA}$

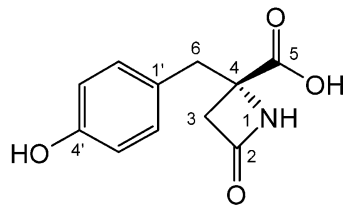

Streptoverticillinone (2)

\section{Experimental}

\section{General}

Optical rotations were obtained on a Perkin-Elmer 341 polarimeter with $\mathrm{MeOH}$ as solvent. The UV spectra were recorded in $\mathrm{MeOH}$ on a Perkin-Elmer Lambda 25 UV-vis spectrophotometer. The ${ }^{1} \mathrm{H}(400 \mathrm{MHz}),{ }^{13} \mathrm{C}(100 \mathrm{MHz})$, and 2D NMR spectra were recorded on a Bruker DRX-400 instrument using TMS as an internal reference. HRTOFMS data were obtained on an API QSTAR TOF mass 
spectrometer in positive-ion mode. ESIMS were collected on MDS SCIEX API 2000 LC/MS/MS instrument. For column chromatography, silica gel $60(100 \sim 200 \mathrm{mesh}$, Qingdao Marine Chemical Ltd., Qingdao, China), Develosil ODS $(10 \mu \mathrm{m}$, Nomura Chemical Co. Ltd., Japan), and Sephadex LH-20 were used. Preparative TLC was performed on precoated silica gel plates $\left(\mathrm{GF}_{254}\right.$, Qingdao Marine Chemical Ltd., Qingdao, China, $0.25 \mathrm{~mm}$ thickness) with detection under fluorescent $(\lambda=254 \mathrm{~nm})$ light.

\section{Producing Actinomycete}

S. morookaense strain SC1169 was isolated from a soil sample (DH0814-5) collected in the pine (Pinus massoniana) forest at Dinghu Mountain Biosphere Reserve, Guangdong, China, in December, 2003. The actinomycete was authenticated by Prof. Songzhen Yang, Guangdong Institute of Microbiology, Guangzhou, China. The culture (SC1169) is deposited in the culture collection of South China Botanical Garden, Chinese Academy of Sciences, Guangzhou, China. For maintenance on agar slants and submerged cultures, the actinomycete was grown on PDA medium.

\section{Fermentation}

The mycelia of $S$. morookaense grown on PDA plates were used to inoculate twenty $100-\mathrm{ml}$ Erlenmeyer flasks containing $30 \mathrm{ml}$ of YMG medium (glucose $0.4 \%$, malt extract $1.0 \%$, yeast extract $0.4 \%, \mathrm{pH} 5.5$ ). The flasks were incubated on a rotary shaker for 5 days in the dark at $25^{\circ} \mathrm{C}$ with shaking at $150 \mathrm{rpm}$. Then the cultures were transferred into twenty 500-ml flasks containing $150 \mathrm{ml}$ of YMG at the same incubation condition. At last the cultures were transferred into twenty 5.0-liter flasks containing $1000 \mathrm{ml}$ of YMG medium and $550 \mathrm{~g}$ of wheat grains, and the cultivation was carried out in the stationary phase in the dark at $25^{\circ} \mathrm{C}$ for 40 days.

\section{Extraction and Isolation}

The solid cultures of $S$. morookaense were extracted with 95\% EtOH three times at room temperature. The resultant EtOH solution, after concentration in vacuo, was suspended in $\mathrm{H}_{2} \mathrm{O}$, and this aqueous suspension was sequentially extracted three times each with petroleum ether, $\mathrm{CHCl}_{3}$, EtOAc, and $n$-BuOH. The EtOAc-soluble extract $(36.7 \mathrm{~g})$ was subjected to passage over a silica gel column, eluted with petroleum ether-acetone mixtures of increasing polarity $(100: 0$ to $3: 2)$ and acetone to obtain ten fractions $(\mathrm{I} \sim \mathrm{X})$. Fraction V, obtained by elution of petroleum ether acetone $(9: 1)$, was chromatographed over a Sephadex LH20 column, eluted with $\mathrm{MeOH}$, to afford $\mathbf{1}(7 \mathrm{mg})$. Fraction
VII, obtained on elution with petroleum ether - acetone (4:1), was applied to a silica gel column with $\mathrm{CHCl}_{3}$ $\mathrm{MeOH}(49: 1)$, to afford cyclo(leucylprolyl) [5] (15 mg) and the mixture of cyclo(isoleucylleucyl) [6] and cyclo(leucylvalyl) [7] (8 mg) in the rough ratio of $3: 2$ (assessed from the ${ }^{1} \mathrm{H}$ NMR signal intensity of $\mathrm{H}-11$ ). Fraction VIII, obtained by elution with petroleum ether acetone $(3: 2)$, was separated by silica gel column chromatography, eluted with $\mathrm{CHCl}_{3}-\mathrm{MeOH}$ mixtures of increasing polarity $(95: 5 \sim 85: 15)$, to afford eight subfractions (VIII-1 VIII-8). Subfraction VIII-6 was subjected to a silica gel column with petroleum ether acetone $(3: 2)$, to afford $\mathbf{2}(20 \mathrm{mg})$.

\section{Streptoverticillin (1)}

Yellowish amorphous powder, $[\alpha]_{\mathrm{D}}^{20}+18.4^{\circ}$ (c 0.179 , $\mathrm{MeOH})$; UV $\lambda_{\max }(\mathrm{MeOH})(\log \varepsilon) 220$ (4.41), 242 (4.48), 293 (4.12), 328 (3.61) nm; ${ }^{1} \mathrm{H}$ NMR (400 MHz, $\left.\mathrm{CD}_{3} \mathrm{OD}\right) \delta$ $8.11(1 \mathrm{H}, \mathrm{d}, J=8.0 \mathrm{~Hz}, \mathrm{H}-5), 7.41(1 \mathrm{H}, \mathrm{d}, J=8.0 \mathrm{~Hz}, \mathrm{H}-8)$, $7.29(1 \mathrm{H}, \mathrm{t}, J=8.0 \mathrm{~Hz}, \mathrm{H}-7), 7.08(1 \mathrm{H}, \mathrm{t}, J=8.0 \mathrm{~Hz}, \mathrm{H}-6)$, $4.09(1 \mathrm{H}, \mathrm{m}, \mathrm{H}-11), 4.03\left(3 \mathrm{H}, \mathrm{s}, \mathrm{OCH}_{3}-4\right), 3.85(3 \mathrm{H}, \mathrm{s}$, $\left.\mathrm{OCH}_{3}-3\right), 3.07(1 \mathrm{H}, \mathrm{dd}, J=6.8,14.0 \mathrm{~Hz}, \mathrm{H}-10 \mathrm{a}), 3.01(1 \mathrm{H}$, dd, $J=6.8,14.0 \mathrm{~Hz}, \mathrm{H}-10 \mathrm{~b}), 2.39$ (3H, s, H-13), 1.22 (3H, d, $J=6.4 \mathrm{~Hz}, \mathrm{H}-12) ;{ }^{13} \mathrm{C}$ NMR $\left(100 \mathrm{MHz}, \mathrm{CD}_{3} \mathrm{OD}\right) \delta 147.5$ (C, C-4), 145.2 (C, C-3), 141.5 (C, C-8a), 138.8 (C, C-9a), 130.0 (C, C-2), 125.9 (CH, C-7), 123.4 (C, C-4b), 123.1 (CH, C-5), 119.6 (CH, C-6), 117.0 (C, C-1), 115.6 (C, C4a), $111.5(\mathrm{CH}, \mathrm{C}-8), 68.9(\mathrm{CH}, \mathrm{C}-11), 61.3\left(\mathrm{OCH}_{3}-3\right)$, $60.8\left(\mathrm{OCH}_{3}-4\right), 38.9\left(\mathrm{CH}_{2}, \mathrm{C}-10\right), 23.1\left(\mathrm{CH}_{3}, \mathrm{C}-12\right), 13.0$ $\left(\mathrm{CH}_{3}, \mathrm{C}-13\right)$; ESIMS m/z $621[2 \mathrm{M}+\mathrm{Na}]^{+}, 599[2 \mathrm{M}+\mathrm{H}]^{+}$, $338[\mathrm{M}+\mathrm{K}]^{+}, \quad 322[\mathrm{M}+\mathrm{Na}]^{+}, \quad 300[\mathrm{M}+\mathrm{H}]^{+}, 282$ $[\mathrm{M}-\mathrm{OH}]^{+}, 254\left[\mathrm{M}-\mathrm{CH}(\mathrm{OH}) \mathrm{CH}_{3}\right]^{+}$; HRTOFMS $\mathrm{m} / \mathrm{z}$ $322.1416[\mathrm{M}+\mathrm{Na}]^{+}$(calcd for $\mathrm{C}_{18} \mathrm{H}_{21} \mathrm{NO}_{3} \mathrm{Na}, 322.1414$ ).

\section{Streptoverticillinone (2)}

White amorphous powder, $[\alpha]_{\mathrm{D}}^{20}+62.8^{\circ}(c$ 0.32, $\mathrm{MeOH})$; UV $\lambda_{\max }(\mathrm{MeOH})(\log \varepsilon) 225$ (3.89), $278(3.17) \mathrm{nm} ;{ }^{1} \mathrm{H}$ NMR (400 MHz, DMSO- $\left.d_{6}\right) \delta 11.06(1 \mathrm{H}, \mathrm{br}$ s, OH-5), 9.26 $\left(1 \mathrm{H}, \mathrm{br}\right.$ s, OH-4'), $7.00\left(2 \mathrm{H}, \mathrm{d}, J=8.0 \mathrm{~Hz}, \mathrm{H}-2^{\prime}, 6^{\prime}\right), 6.63$ $\left(2 \mathrm{H}, \mathrm{d}, J=8.0 \mathrm{~Hz}, \mathrm{H}-3^{\prime}, 5^{\prime}\right), 6.04(1 \mathrm{H}, \mathrm{br} \mathrm{s}, \mathrm{H}-1), 2.87$ and 2.77 (each $1 \mathrm{H}, \mathrm{d}, J=16.0 \mathrm{~Hz}, \mathrm{H}_{2}-6$ ), 2.73 and 2.34 (each $\left.1 \mathrm{H}, \mathrm{d}, J=16.0 \mathrm{~Hz}, \mathrm{H}_{2}-3\right) ;{ }^{13} \mathrm{C}$ NMR $\left(400 \mathrm{MHz}\right.$, DMSO- $\left.d_{6}\right)$ $\delta 181.0(\mathrm{C}, \mathrm{C}-5), 175.6$ (C, C-2), $156.2\left(\mathrm{C}, \mathrm{C}-4^{\prime}\right), 131.1$ $\left(\mathrm{CH}, \mathrm{C}-2^{\prime}, 6^{\prime}\right), 125.4\left(\mathrm{C}, \mathrm{C}-1^{\prime}\right), 115.0\left(\mathrm{CH}, \mathrm{C}-3^{\prime}, 5^{\prime}\right), 76.3$ (C, C-4), $41.5\left(\mathrm{CH}_{2}, \mathrm{C}-3\right), 41.3\left(\mathrm{CH}_{2}, \mathrm{C}-6\right)$; ESIMS $\mathrm{m} / \mathrm{z} 465$ $[2 \mathrm{M}+\mathrm{Na}]^{+}, 260[\mathrm{M}+\mathrm{K}]^{+}, 222[\mathrm{M}+\mathrm{H}], 205[\mathrm{M}-\mathrm{OH}]^{+}$; HRTOFMS $m / z \quad 244.0570 \quad[\mathrm{M}+\mathrm{Na}]^{+} \quad($ calcd for $\mathrm{C}_{11} \mathrm{H}_{11} \mathrm{NO}_{4} \mathrm{Na}, 244.0580$ ).

\section{Preparation of $(R)$ - and $(S)$-MTPA Esters of 1}

A solution of the compound $(1.2 \mathrm{mg}, 0.004 \mathrm{mmol})$ in 
$\mathrm{CH}_{2} \mathrm{Cl}_{2}$ (1.0 ml) was treated with $(R)-\alpha$-methoxy- $\alpha$ trifluoromethylphenylacetic acid [(R)-MTPA, $4.7 \mathrm{mg}$, $0.02 \mathrm{mmol}]$ in the presence of 1-ethyl-3-(3-dimethylaminopropyl)-carbodiimide hydrochloride (EDC- $\mathrm{HCl}, 3.8 \mathrm{mg}$, $0.02 \mathrm{mmol}$ ) and 4-dimethylaminopyridine (4-DMAP, $2.4 \mathrm{mg}, 0.02 \mathrm{mmol}$ ), and the mixture was stirred at room temperature $\left(20^{\circ} \mathrm{C}\right)$ for 24 hours. The reaction mixture was poured into ice-water and the whole was extracted with EtOAc. The EtOAc extract was successively washed with $5 \%$ aq $\mathrm{HCl}$, aq sat $\mathrm{NaHCO}_{3}$, and brine, then dried over $\mathrm{MgSO}_{4}$ and filtered. Evaporation of the solvent from the filtrate under reduced pressure furnished a residue, which was purified by preparative TLC, developed with petroleum ether-EtOAc $(9: 1)$ to give $(R)$-MTPA ester $(1.5 \mathrm{mg})$. Through a similar procedure, the $(S)$-MTPA ester $(1.3 \mathrm{mg})$ was prepared from the compound $(1.2 \mathrm{mg})$ by the use of $(S)$-MTPA (4.7 mg), EDC-HCl (3.8 mg), and 4-DMAP $(2.4 \mathrm{mg})$.

(R)-MTPA Ester of 1 (1a): ${ }^{1} \mathrm{H}$ NMR $\left(400 \mathrm{MHz}, \mathrm{CDCl}_{3}\right)$ $\delta 1.412(3 \mathrm{H}, \mathrm{d}, J=6.2 \mathrm{~Hz}, \mathrm{H}-12), 2.413(3 \mathrm{H}, \mathrm{s}, \mathrm{H}-13)$, $3.133(1 \mathrm{H}, \mathrm{dd}, J=7.4,14.4 \mathrm{~Hz}, \mathrm{H}-10 \mathrm{~b}), 3.282(1 \mathrm{H}, \mathrm{dd}$, $J=6.0,14.4 \mathrm{~Hz}, \mathrm{H}-10 \mathrm{a}), 3.282$ ( $3 \mathrm{H}, \mathrm{s}, \mathrm{OCH}_{3}$-MTPA), 3.889 $\left(3 \mathrm{H}, \mathrm{s}, \mathrm{OCH}_{3}-3\right), 4.118\left(3 \mathrm{H}, \mathrm{s}, \mathrm{OCH}_{3}-4\right), 5.332(1 \mathrm{H}, \mathrm{m}, \mathrm{H}-$ 11), $7.20 \sim 7.39(8 \mathrm{H}$, overlapping, H-Ar), $8.203(1 \mathrm{H}, \mathrm{d}$, $J=7.8 \mathrm{~Hz}, \mathrm{H}-5), 8.676$ (1H, br s, H-9).

$(S)$-MTPA Ester of $\mathbf{1}(\mathbf{1 b}):{ }^{1} \mathrm{H}$ NMR $\left(400 \mathrm{MHz}, \mathrm{CDCl}_{3}\right) \delta$ 1.408 (3H, d, $J=6.3 \mathrm{~Hz}, \mathrm{H}-12), 2.392$ (3H, s, H-13), 3.053 $(1 \mathrm{H}, \mathrm{dd}, J=8.0,14.0 \mathrm{~Hz}, \mathrm{H}-10 \mathrm{~b}), 3.303(1 \mathrm{H}, \mathrm{dd}, J=4.6$, $\left.14.0 \mathrm{~Hz}, \mathrm{H}_{2}-10 \mathrm{a}\right), 3.538\left(3 \mathrm{H}, \mathrm{s}, \mathrm{OCH}_{3}-\mathrm{MTPA}\right), 3.879(3 \mathrm{H}$, s, $\left.\mathrm{OCH}_{3}-3\right), 4.111\left(3 \mathrm{H}, \mathrm{s}, \mathrm{OCH}_{3}-4\right), 5.369(1 \mathrm{H}, \mathrm{m}, \mathrm{H}-11)$, $7.19 \sim 7.47$ (8H, overlapping, H-Ar), 8.197 (d, $J=8.0 \mathrm{~Hz}$, H-5), 8.944 (1H, br s, H-9).

\section{Antifungal Activity Test}

Antifungal activity was evaluated by the well plate diffusion method [8]. The test microorganism was P. litchii, obtained from Key Laboratory of Pesticides and Chemical Biology, Ministry of Education, South China Agriculture University, Guangzhou, China. Compounds 1, 2 and carbendazim (positive control) were individually dissolved and diluted with DMSO to obtain serial concentrations of 2000, 1000, 500, 250, and $125 \mu \mathrm{g} / \mathrm{ml}$. Three $6 \mathrm{~mm}$ wide wells were opened in the PDA medium inoculated test microorganism in each Petri dish using a sterile steel borer. The compound solution $(100 \mu 1)$ of a specific concentration was added to each of the wells. DMSO was used as a negative control. The plates were then incubated at $25^{\circ} \mathrm{C}$ for 3 days. The inhibition zones around the holes were measured and MIC which was defined as the lowest concentration able to inhibit any visible fungal growth was recorded. The assays were performed three times for each compound in order to guarantee reproducibility of results.

\section{Results and Discussion}

The actinomycete, S. morookaense strain SC1169, was isolated from a soil sample collected from Dinghu Mountain Biosphere Reserve, Guangdong, China. The mycelia were grown on a solid culture for 40 days at $25^{\circ} \mathrm{C}$ in the dark. The EtOH extract of the mycelial culture was sequentially fractionated with petroleum ether, $\mathrm{CHCl}_{3}$, and EtOAc. The EtOAc-soluble extract, by separation with silica gel and Sephadex LH-20 column chromatography, yielded compounds $\mathbf{1}$ and $\mathbf{2}$ along with cyclo(leucylprolyl) [5] and a mixture of cyclo(isoleucylleucyl) [6] and cyclo(leucylvalyl) [7], which were identified by interpretation of their spectroscopic (ESIMS, ${ }^{1} \mathrm{H}$ NMR, and ${ }^{13} \mathrm{C} \mathrm{NMR}$ ) data as well as by comparison of their physical and spectroscopic data with those in the indicated literatures.

1 had a molecular formula of $\mathrm{C}_{18} \mathrm{H}_{21} \mathrm{NO}_{3}$ by analysis of its HRTOFMS, ${ }^{13} \mathrm{C}$ NMR and DEPT data. The ${ }^{1} \mathrm{H}$ NMR spectrum (see Experimental section) in combination with the COSY spectrum (Fig. 1) showed the presence of an aromatic methyl group at $\delta 2.39(3 \mathrm{H}, \mathrm{s}, \mathrm{H}-13)$, two aromatic methoxyl groups at $\delta 3.85\left(3 \mathrm{H}, \mathrm{s}, \mathrm{OCH}_{3}-3\right)$ and $4.03\left(3 \mathrm{H}, \mathrm{s}, \mathrm{OCH}_{3}-4\right)$, a 2-hydroxypropyl group $[\delta 1.22$ $(3 \mathrm{H}, \mathrm{d}, J=6.4 \mathrm{~Hz}, \mathrm{H}-12), 4.09(1 \mathrm{H}, \mathrm{m}, \mathrm{H}-11), 3.01(1 \mathrm{H}, \mathrm{dd}$, $J=6.8,14.0 \mathrm{~Hz}, \mathrm{H}-10 \mathrm{~b})$, and $3.07(1 \mathrm{H}, \mathrm{dd}, J=6.8,14.0 \mathrm{~Hz}$, $\mathrm{H}-10 \mathrm{a})]$, and a 1,2-disubstituted benzene ring $[\delta 7.08(1 \mathrm{H}$, $\mathrm{t}, J=8.0 \mathrm{~Hz}, \mathrm{H}-6), 7.29(1 \mathrm{H}, \mathrm{t}, J=8.0 \mathrm{~Hz}, \mathrm{H}-7), 7.41(1 \mathrm{H}, \mathrm{d}$, $J=8.0 \mathrm{~Hz}, \mathrm{H}-8)$, and $8.11(1 \mathrm{H}, \mathrm{d}, J=8.0 \mathrm{~Hz}, \mathrm{H}-5)]$. These groups were also indicated by the ${ }^{13} \mathrm{C}$ NMR and DEPT spectra. Besides, the ${ }^{13} \mathrm{C}$ NMR (see Experimental section) spectrum exhibited the signals at $\delta 117.0(\mathrm{C}-1), 130.0$ (C-2), 145.2 (C-3), 147.5 (C-4), 115.6 (C-4a), and 138.8 (C-9a) for a fully substituted benzene ring. The connectivities among these groups were readily derived from the HMBC correlations as shown in Fig. 1. On the basis of the above

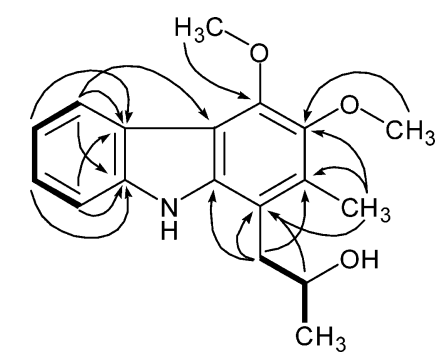

Fig. $1 \quad{ }^{1} \mathrm{H}-{ }^{1} \mathrm{H}$ COSY (bold line) and key HMBC correlations (arrow) of $\mathbf{1}$. 
evidence, the basic structure of 1 was determined as 1-(2hydroxypropyl)-3,4-dimethoxy-2-methyl-9H-carbazole.

In order to establish the absolute configuration at C-11, the modified Mosher's method [9] was applied as the configuration of carquinostatin A, a carbozole structurally related to $\mathbf{1}$, was successfully determined by using this method [10]. Treatment of 1 with $(R)$ - and (S)-MTPA in the presence of EDC-HCl using catalytic DMAP afforded $(R)$ - and (S)-MTPA esters (1a and $\mathbf{1 b}$, respectively) (see Experimental section). However, analysis of the proton chemical shift differences showed the irregular distribution of $\Delta \delta\left(\delta_{S}-\delta_{R}\right)$ signs [negative for $\mathrm{H}$ $10 \mathrm{~b}(-0.080), \mathrm{H}-12(-0.004)$, and $\mathrm{H}-13(-0.021)$, and positive for $\mathrm{H}-10 \mathrm{a}(+0.021)$ and $\mathrm{H}-11 \quad(+0.037)]$, indicating that the method was inapplicable to this compound. Furthermore, the limited amount of compound sample did not allow us to try other methods. But then, the enantioselective synthesis of neocarazostatin B and its analogues, which are closely similar to $\mathbf{1}$ in both the basic structure and chiral center, were reported and these synthetic compounds, all with $11 R$ configuration, showed negative optical rotation values. However, 1 demonstrated the positive optical rotation with value similar to that of neocarazostatin $\mathrm{B}$ in $\mathrm{MeOH}\left([\alpha]_{\mathrm{D}}^{20}+18.4^{\circ}\right.$ against $[\alpha]_{\mathrm{D}}^{25}$ $-16^{\circ}$ in neocarazostatin B) and should, therefore, have $11 S$ absolute configuration.

2 had a molecular formula, $\mathrm{C}_{11} \mathrm{H}_{11} \mathrm{NO}_{4}$, as determined by analysis of its HRTOFMS, ESIMS, and NMR $\left({ }^{1} \mathrm{H},{ }^{13} \mathrm{C}\right.$, and DEPT) data. The ${ }^{1} \mathrm{H}$ and ${ }^{13} \mathrm{C}$ NMR spectra of 2 (see Experimental section) revealed the presence of two isolate methylenes $\left[\delta_{\mathrm{H}} 2.34\right.$ and 2.73 (each $1 \mathrm{H}, \mathrm{d}, J=16.0 \mathrm{~Hz}, \mathrm{H}_{2}-$ $3), \delta_{\mathrm{C}} 41.5(\mathrm{C}-3) ; \delta_{\mathrm{H}} 2.77$ and 2.87 (each $1 \mathrm{H}$, d, $\left.\left.J=16.0 \mathrm{~Hz}, \mathrm{H}_{2}-6\right), \delta_{\mathrm{C}} 41.3(\mathrm{C}-6)\right]$, a carboxyl group [ $\delta_{\mathrm{H}}$ $11.06\left(1 \mathrm{H}\right.$, br s, OH-5), $\left.\delta_{\mathrm{C}} 181.0(\mathrm{C}-5)\right]$, an acylamino group $\left[\delta_{\mathrm{H}} 6.04(1 \mathrm{H}, \mathrm{brs}, \mathrm{H}-1), \delta_{\mathrm{C}} 175.6(\mathrm{C}-2)\right]$, as well as a $p$-hydroxylphenyl group $\left[\delta_{\mathrm{H}} 7.00\left(2 \mathrm{H}, \mathrm{d}, J=8.0 \mathrm{~Hz}, \mathrm{H}-2^{\prime}\right.\right.$ and $\left.6^{\prime}\right), 6.63\left(2 \mathrm{H}, \mathrm{d}, J=8.0 \mathrm{~Hz}, \mathrm{H}-3^{\prime}\right.$ and $\left.5^{\prime}\right)$, and $9.26(1 \mathrm{H}$, brs, OH-4'), $\delta_{\mathrm{C}} 125.4\left(\mathrm{C}-1^{\prime}\right), 131.1\left(\mathrm{C}-2^{\prime}\right.$ and $\left.6^{\prime}\right), 115.0$ $\left(\mathrm{C}-3^{\prime}\right.$ and $\left.5^{\prime}\right)$, and $\left.156.2\left(\mathrm{C}-4^{\prime}\right)\right]$. The HMBC correlations (Fig. 2) from $\mathrm{H}-1$ and $\mathrm{H}_{2}-3$ to $\mathrm{C}-2, \mathrm{C}-4, \mathrm{C}-5$, and $\mathrm{C}-6$, from $\mathrm{H}_{2}-6$ to $\mathrm{C}-1^{\prime}, \mathrm{C}-2^{\prime}, \mathrm{C}-6^{\prime}, \mathrm{C}-3, \mathrm{C}-4$, and $\mathrm{C}-5$, and from $\mathrm{H}-1$ to $\mathrm{C}-3$ indicated a connectivity of $\mathrm{N}-1, \mathrm{C}-2, \mathrm{C}-3$, and $\mathrm{C}-4$ to create a 2-azetidinone ring with a carboxyl group and a $p$ hydroxylbenzyl group attached to $\mathrm{C}-4$. The configuration at C-4 was tentatively determined as $S$ by comparison of its optical rotation value with those of previously synthesized 4-benzyl-4-carboxy-2-azetidinone derivatives [14]. Thus, 2 was elucidated as (4S)-4-( $p$-hydroxybenzyl)-4-carboxy-2azetidinone.

In an assessment of antifungal activity by the well plate diffusion method [8] using carbendazim, a commercial

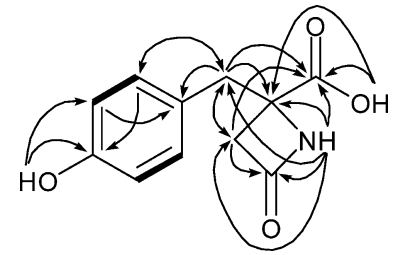

Fig. $2{ }^{1} \mathrm{H}-{ }^{1} \mathrm{H}$ COSY (bold line) and key HMBC correlations (arrow) of 2.

antifungal agent, as a positive control, both $\mathbf{1}$ and $\mathbf{2}$ exhibited potency against $P$. litchii. The MICs of $\mathbf{1}$ and $\mathbf{2}$ against $P$. litchii were 250 and $1000 \mu \mathrm{g} / \mathrm{ml}$, respectively. The potency of 1 was equivalent to that of carbendazim.

Acknowledgment We thank Prof. Songzhen Yang, Guangdong Institute of Microbiology, for microbiological authentication, and Dr. Dongmei Fang, Chengdu Institute of Biology, Chinese Academy of Sciences, for HRTOFMS data. This work was supported by an NSFC grant (No.20672114).

\section{References}

1. Wang J, Zhu X. Postharvest diseases of litchi and the research progress on their Control. Journal Fruit Science 19: 128-131 (2002)

2. Vining LC. Functions of secondary metabolites. Annu Rev Microbiol 44: 395-427 (1990)

3. Ma W, Huang Y, Lin L, Zhu X, Chen Y, Xu H, Wei X. Two new biologically active illudane sesquterpenes from the mycelial cultures of Panaeolus retirugis. J Antibiot 57: $721-725$ (2004)

4. Xu L, Xue J, Xu H, Liu X, Ma W, Wei X. Three new isochromans from the mycelial culture of a Cylindrocarpon fungus. Heterocycles 68: 1955-1959 (2006)

5. Adamczeski M, Reed AR, Crews P. New and known diketopiperazines from the Caribbean sponge, Calyxcf Podatypa. J Nat Prod 58: 201-208 (1995)

6. Kang J, Chen R. Studies on chemical constituents of the mycelia from fermented culture of Flammulina velutipes. China Journal Chinese Materia Medica 28: 1038-1040 (2003)

7. Wang S, Tan N, Yang Y, He M. Cyclodipeptides from the roots of Panax notoginseng. Natural Product Research Development 16: 383-386 (2004)

8. Brantner A. Evaluation of pharmacopoeia methods for determination of antimicrobial agents, especially of natural substances. Pharmazie 52: 34-40 (1997)

9. Ohtani I, Kusumi T, Kashman Y, Kakisawa H. High-field FT NMR application of Mosher's method. The absolute configurations of marine terpenoids. J Am Chem Soc 113: 
4092-4096 (1991)

10. Shin-ya K, Tanaka M, Furihata K, Hayakawa Y, Seto H. Structure of carquinostatin A, a new neuronal cell protecting substance produced by Streptomyces exfoliatus. Tetrahedron Lett 34: 4943-4944 (1993)

11. Seco JM, Quiñoá E, Riguera R. The assignment of absolute configuration by NMR. Chem Rev 104: 17-118 (2004)

12. Kato S, Shindo K., Kataoka Y, Yamagishi Y, Mochizuki J. Studies on free radical scavenging substances from microorganisms. II. Neocarazostatins A, B and C, novel free radical scavengers. J Antibiot 44: 903-907 (1991)

13. Czerwonka R, Reddy KR, Baum E, Knolker HJ. First enantioselective total synthesis of neocarazostatin B, determination of its absolute configuration and transformation into carquinostatin A. Chem Commun 21: 711-713 (2006)

14. Gerona-Navarro G, García-López MT, González-Muñiz R. General approach for the stereocontrolled construction of the $\beta$-lactam ring in amino acid-derived 4-alkyl-4-carboxy2-azetidinones. J Org Chem 67: 3953-3956 (2002) 